\title{
Topical application of mupirocin to exit sites in patients on peritoneal dialysis: a systematic review and meta-analysis of randomized controlled trials
}

Yoko Obata ${ }^{1,2}$, Miho Murashima ${ }^{1,3^{*}}$, Naohiro Toda ${ }^{1,4}$, Shuto Yamamoto ${ }^{1,5}$, Yoshihiro Tsujimoto ${ }^{1,6}$, Yasushi Tsujimoto ${ }^{1,7}$, Hiraku Tsujimoto ${ }^{1,8}$, Hidemichi Yuasa ${ }^{1,9}$, Munekazu Ryuzaki ${ }^{1,10}$, Yasuhiko Ito 1,11, Tadashi Tomo ${ }^{1,12}$ and Hidetomo Nakamoto ${ }^{1,13}$

\begin{abstract}
Background: The International Society for Peritoneal Dialysis guidelines recommends the topical application of antibiotics on the exit site for the prevention of peritoneal dialysis (PD)-related infections. However, the recommendation is based on meta-analyses on applying nasal mupirocin ointment or observational or retrospective studies. Here, we evaluated the efficacy of topical application of mupirocin on the exit site for the prevention of PD-related infections.

Methods: We searched the databases, MEDLINE and CENTRAL, documenting the topical application of antibiotics on the exit site in PD patients in April 2017. We included only randomized controlled trials (RCTs) with adult patients wherein the effects of mupirocin were examined. Exit site infection (ESI), peritonitis, and technical failure were assessed as the main outcomes.
\end{abstract}

Results: Overall, six RCTs were included in this study. It was uncertain whether the application of mupirocin ointment prevents ESI (rate ratio (RR), 0.36; 95\% Cl, 0.13-1.05), peritonitis (RR 0.78, 95\% Cl 0.50-1.21), and technical failure (RR, 1.35; $95 \% \mathrm{Cl}, 0.25-7.21)$. Moreover, a comparison between mupirocin and gentamicin showed no difference in the incidence of ESI (RR, 1.14; 95\% Cl, 0.27-4.81), peritonitis (RR, 0.85; 95\% Cl, 0.32-2.26), and technical failure (RR, 0.58; 95\% Cl, 0.28-1.20).

Conclusions: It remains unclear whether topical application of mupirocin on the exit site has any significant effects on PD-related infection or technical failure. Large-scale RCTs with high methodological quality are required to confirm the efficacy of topical application of antibiotics on the exit site.

(Continued on next page)

\footnotetext{
* Correspondence: mmurashi@med.nagoya-cu.ac.jp

${ }^{1}$ Working Group on Revision of Peritoneal Dialysis Guidelines, Japanese

Society for Dialysis Therapy, 2-38-21, Hongo, Bunkyo-ku, Tokyo 1130033,

Japan

${ }^{3}$ Department of Nephrology, Nagoya City University Graduate School of

Medical Sciences, 1-Kawasumi, Mizuho-cho, Mizuho-ku, Nagoya 467-8601,

Japan

Full list of author information is available at the end of the article
}

(c) The Author(s). 2020 Open Access This article is licensed under a Creative Commons Attribution 4.0 International License, which permits use, sharing, adaptation, distribution and reproduction in any medium or format, as long as you give appropriate credit to the original author(s) and the source, provide a link to the Creative Commons licence, and indicate if changes were made. The images or other third party material in this article are included in the article's Creative Commons licence, unless indicated otherwise in a credit line to the material. If material is not included in the article's Creative Commons licence and your intended use is not permitted by statutory regulation or exceeds the permitted use, you will need to obtain permission directly from the copyright holder. To view a copy of this licence, visit http://creativecommons.org/licenses/by/4.0/. The Creative Commons Public Domain Dedication waiver (http://creativecommons.org/publicdomain/zero/1.0/) applies to the data made available in this article, unless otherwise stated in a credit line to the data. 
(Continued from previous page)

Trial registration: UMINR000039267

Keywords: Peritoneal dialysis, Topical application, Exit site, Mupirocin, Gentamicin, Exit site infection, Peritonitis, Technical failure

\section{Background}

Peritoneal dialysis (PD) is one of the renal replacement therapies for end-stage renal disease. However, there is a wide variation in rates of exit-site infection (ESI) or peritonitis in different centers and countries. The ESI incidence rate is 0.40 episodes/patient-year in Japan [1], and the reported peritonitis rates range from 0.06 to $1.66 \mathrm{ep}-$ isodes/patient-year [2, 3]. Although technological advancements in PD improve recently, these PD-related infections have been a major cause of hospitalization [4], technical failure [5], and death [6] in PD patients. Therefore, it is important to prevent PD-related infections.

The International Society for Peritoneal Dialysis (ISPD) guidelines recommended daily topical application of antibiotic agents on the exit site [7]. Among the antibiotic agents applied on the exit site, mupirocin ointment has been reported to reduce the risk of PD-related infections [8-13]. Mupirocin is a competitive inhibitor of bacterial isoleucyl-transfer ribonucleic acid synthetase, leading to bacterial death, and it has been widely used in methicillin-resistant Staphylococcus aureus (MRSA) prevention and specifically for the eradication of nasal MRSA. Mupirocin ointment applied as prophylaxis on the exit site has been shown to be effective in reducing ESI due to $S$. aureus [14]. The ISPD guidelines' recommendation, however, were based on the previous metaanalyses including the studies that targeted patients applying nasal mupirocin ointment or nasal carriers of Staphylococcus or retrospective studies [13] that should be meta-analyzed and presented separately from randomized controlled trials (RCTs) [15]. Moreover, several RCTs were published since the publication of metaanalyses [16-18]. Therefore, these results might lead to misleading interpretation on the establishment of the guidelines. Thus, we evaluate the efficacy of topical application of mupirocin ointment on the exit site for the prevention of PD-related infection using RCTs in this systematic review (SR). Additionally, we compared mupirocin with gentamicin that were reported to reduce ESI caused by gram-negative bacteria [19].

\section{Methods}

\section{Design and setting of the study}

This is a SR with meta-analysis that assesses whether the application of mupirocin ointment on the exit site is effective in preventing ESI, peritonitis, or technical failure in PD patients. We also assessed whether the application of mupirocin ointment is better compared with the application of gentamicin ointment on the exit site in preventing ESI, peritonitis, or technical failure. This review is reported in accordance with the Preferred Reporting Items for Systematic Reviews and Meta-Analyses (PRISMA) guidelines [20]. The protocol used for the SR and meta-analysis was registered in the University Hospital Medical Information Network (registration number, R000039267). No ethical approval was required because this study did not include confidential personal data and did not involve patient intervention.

\section{Inclusion and exclusion criteria}

We included only RCTs that compared the effects of the application of mupirocin ointment and gentamicin ointment on the exit site. We included PD patients who were 18 years old and older. We excluded patients with preexisting infections. The intervention was the application of mupirocin ointment on the exit site. We excluded the nasal application of antibiotics. The control condition was no antibiotic ointment (including application of disinfectant only) or gentamicin ointment. We included and translated the studies published in non-English language. A translation service, Glova, Co. (Tokyo, Japan), performed the translation. Our primary outcomes were ESI, peritonitis, and technical failure.

\section{Search strategy and study selection}

The electronic databases, MEDLINE and the Cochrane Central Register of Controlled Trials (CENTRAL) (until April 10, 2017), were searched for studies meeting our inclusion criteria. The search strategy is described in the appendix. Five reviewers (N.T., Y.O., Yo.T., S.Y., and M.T.) independently screened all titles, abstracts, and full texts of the selected publications. We resolved disagreements by discussion between the authors, with another author (Ya.T.) acting as an arbiter.

\section{Data extraction and quality assessment}

Five reviewers (N.T., Y.O., Yo.T., S.Y., and M.T.) independently extracted trial-level data using prespecified forms. We resolved disagreements regarding data extraction through discussions with another author (Ya.T.) acting as an arbiter. 
The methodological quality of trials included in the review was assessed independently using the Cochrane Collaboration tool [21] by five reviewers (N.T., Y.O., Y.T., S.Y., and M.T.) to determine the risk of bias. Studies were graded as having a "low risk," "high risk, " or "unclear risk" of bias across the seven specified domains: random sequence generation, allocation concealment, participant and personnel blinding, outcome assessment blinding, incomplete outcome data, selective reporting, and other sources of bias. We resolved disagreements regarding data extraction through discussions with another author (Ya.T.) acting as an arbiter. We graded the certainty of evidence for each of the main outcomes, which was evaluated using the Grading of Recommendations, Assessment, Development, and Evaluation approach [22].

\section{Data analysis and statistical methods}

We performed all analyses using the Cochrane Review Manager software (RevMan 5.3; Cochrane Collaboration, Copenhagen, Denmark). We used rate ratios to compare the efficacy of the intervention on the outcomes. We calculated the incidence rate using events per patient-years and compared the incidence rate between the intervention and control groups. When there were participants who dropped out from the study, the data were included if the timing of dropout and the number of events up to the time of dropout were reported, and the data were excluded if these data were not reported. Data were pooled using the random effects model. Heterogeneity was analyzed using the chi-squared test on N-1 degrees of freedom, with an alpha of 0.05 considered to be statistically significant and with the $I^{2}$ test [23]. $I^{2}$ values of 25\%, $50 \%$, and $75 \%$ correspond to low, medium, and high levels of heterogeneity, respectively.

\section{Results}

\section{Study selection}

The PRISMA flowchart in Fig. 1 summarizes the search process. Among the 11 clinical practice guidelines (CPGs) and SRs [11, 24-33] identified, 3 SRs published most recently were considered [24-26]. Fifty-one references were cited in these SRs. Among them, 4 studies met our criteria $[9,16,19,34]$. Further database search for more recent articles identified 1 CPG [7] and 1 RCT [17] meeting our inclusion criteria. One more RCT cited in the CPG [18] was included. Overall, 6 RCTs were included in this systematic review.

\section{Characteristics of the included studies}

Among the 6 studies, 3 studies compared the application of mupirocin ointment with no antibiotic ointment on the exit site $[16,18,34]$, and the other 3 studies compared the application of mupirocin ointment with gentamicin ointment on the exit site [9, 17, 19] (Table 1). An erratum [35] for authors' names was published for the study by Olga et al. [16]. The study has been cited in other articles as Olga et al. and to avoid confusion in this study, the study was cited as Olga 2016 rather than Balafa 2017. A study written in Persian [17] was translated into English for assessment. In the 3 studies comparing mupirocin ointment and the control, there were 159 patients in the mupirocin group and 163 patients in the control group. Five patients in the mupirocin group and 7 patients in the control group dropped out in 1 study [34]. The timing of dropout was not reported, and thus, these patients were excluded from the analyses. Three studies were included for the comparison between mupirocin and gentamicin ointment. There were 165 patients in the mupirocin group and 170 patients in the gentamicin group. It was unclear how the number of ESI was counted in 1 study [17]; therefore, this study was excluded from the analyses for ESI. Two studies were analyzed for the rates of ESI (104 and 110 patients in the mupirocin and the gentamicin group, respectively). There were 14 patients who dropped out from the study according to Chu et al. [9]. It was not reported whether they belonged to the mupirocin or gentamicin group, and thus, these patients were excluded from the analyses. Four patients in the mupirocin group and 3 patients in the gentamicin group dropped out from the study according to Mortazavi et al. [17].

\section{Risk of bias in the included studies}

The risk of bias is shown in Table 2. None of the studies on the comparison between mupirocin ointment and the control were blinded, and follow-up was incomplete in one study [34]. If all subjects who dropped out from the control group developed events after dropout, it would change the point of estimate to the opposite direction for technical failure. Thus, the risk of bias for incomplete outcome data was considered high.

\section{Comparison between mupirocin ointment and no antibiotic ointment}

As shown in Fig. 2a, it was uncertain whether the application of mupirocin ointment prevents ESI (rate ratio [RR], 0.36; 95\% confidence interval [CI], 0.131.05; very low evidence). The heterogeneity was substantial $\left(I^{2}=61 \%\right)$. Mupirocin ointment may slightly reduce peritonitis $(\mathrm{RR}, 0.78 ; 95 \% \mathrm{CI}, 0.50-1.21$; low evidence; Fig. 2b). There was no heterogeneity $\left(I^{2}=\right.$ $0 \%)$. Mupirocin may have little or no significant 


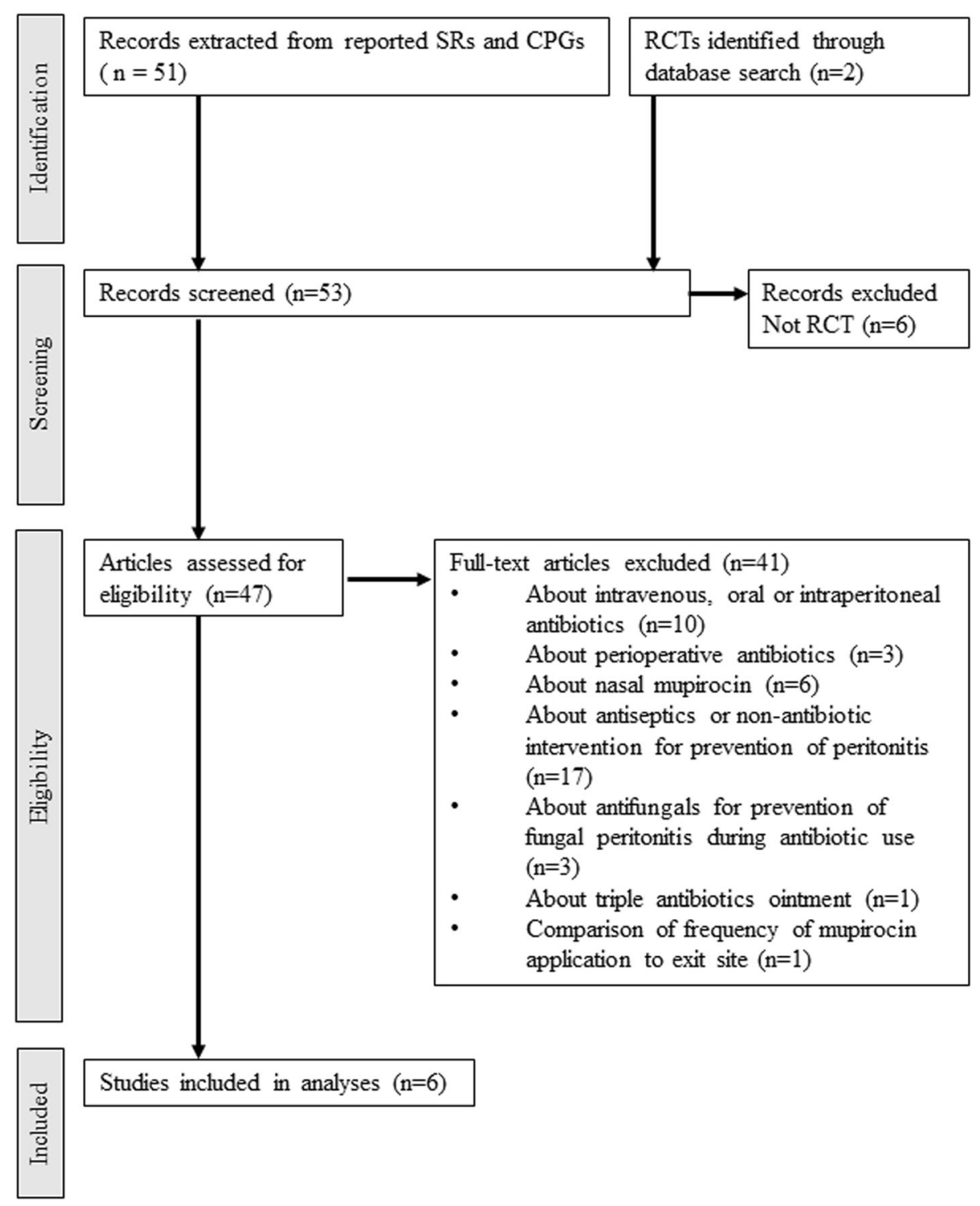

Fig. 1 Flowchart for study selection. CPG clinical practice guideline, SR systematic review, RCT randomized controlled trial

difference in technical failure (RR, 1.35; 95\% CI, 0.25-7.21; low evidence; Fig. 2c). The heterogeneity was low $\left(I^{2}=12 \%\right)$. The summary of the findings is shown in Table 3. Overall, the quality of evidence was low or very low.

\section{Comparison between mupirocin ointment and gentamicin ointment}

As shown in Fig. 2d, it was unclear whether the application of mupirocin ointment reduces ESI compared with gentamicin ointment (RR, 1.14; 95\% CI, 0.27-4.81; very low evidence). The heterogeneity was considerable $\left(I^{2}=87 \%\right)$. Three studies reported the rate of peritonitis and technical failure. The application of mupirocin ointment may have little or no significant difference in peritonitis compared with gentamicin ointment (RR, 0.85; 95\% CI, 0.32-2.26; $I^{2}$ $=66 \%$, low evidence; Fig. 2e). Two studies reported the rate of technical failure (Fig. 2f). The application of mupirocin ointment may slightly reduce technical failure compared with gentamicin ointment (RR, 0.58; 95\% CI, 0.28-1.20; $I^{2}=0 \%$; low evidence). The summary of the findings is shown in Table 3. Overall, the quality of evidence was very low to low.

\section{Discussion}

In this $\mathrm{SR}$, it is uncertain whether the application of mupirocin or gentamicin ointments on the exit site 
Table 1 Characteristics of the included studies

\begin{tabular}{|c|c|c|c|c|c|c|c|}
\hline Study & $\begin{array}{l}\text { Design } \\
\text { follow-up }\end{array}$ & Participants & Inclusion & Exclusion & Interventions & Outcomes & Notes \\
\hline $\begin{array}{l}\text { Wong } \\
\text { et al. [34] }\end{array}$ & $\begin{array}{l}\text { RCT } 5 \\
\text { months }\end{array}$ & $\begin{array}{l}\text { Countries, } \\
\text { Hong } \\
\text { Kong; } \\
\text { setting, } \\
\text { single } \\
\text { center }\end{array}$ & $\begin{array}{l}\text { Both incident and } \\
\text { prevalent PD } \\
\text { patients }\end{array}$ & $\begin{array}{l}\text { Psychiatric, } \\
\text { dermatological, or } \\
\text { terminal illness; presence } \\
\text { of peritonitis or ESI; the } \\
\text { use of antibiotics within a } \\
\text { month }\end{array}$ & $\begin{array}{l}\text { Mupirocin, } n \\
=73 ; \\
\text { control, } n= \\
81 ; \text { dropout, } \\
n=12\end{array}$ & $\begin{array}{l}\text { ESI, } \\
\text { peritonitis, } \\
\text { technical } \\
\text { failure }\end{array}$ & Funding source was not stated. \\
\hline $\begin{array}{l}\text { Olga et al. } \\
\text { [16] }\end{array}$ & $\begin{array}{l}\text { RCT } 86.7 \\
\text { patient- } \\
\text { years for M, } \\
60.4 \\
\text { patient- } \\
\text { years for } \mathrm{C}\end{array}$ & $\begin{array}{l}\text { Countries, } \\
\text { Greece; } \\
\text { setting, } \\
\text { single } \\
\text { center }\end{array}$ & $\begin{array}{l}\text { Both incident and } \\
\text { prevalent PD } \\
\text { patients }\end{array}$ & $\begin{array}{l}\text { Peritonitis or ESI within } 3 \\
\text { months }\end{array}$ & $\begin{array}{l}\text { Mupirocin, } n \\
=33 \\
\text { control, } n= \\
29\end{array}$ & $\begin{array}{l}\text { ESI, } \\
\text { peritonitis, } \\
\text { technical } \\
\text { failure }\end{array}$ & Funding source was not stated. \\
\hline $\begin{array}{l}\text { Findaly } \\
\text { et al. [18] }\end{array}$ & $\begin{array}{l}\text { RCT } 58.1 \\
\text { patient- } \\
\text { years for M, } \\
53.9 \\
\text { patient- } \\
\text { years for C }\end{array}$ & $\begin{array}{l}\text { Countries, } \\
\text { United } \\
\text { Kingdom; } \\
\text { setting, not } \\
\text { stated }\end{array}$ & $\begin{array}{l}\text { Both incident and } \\
\text { prevalent PD } \\
\text { patients }\end{array}$ & $\begin{array}{l}\text { Peritonitis or ESI within a } \\
\text { month }\end{array}$ & $\begin{array}{l}\text { Mupirocin, } n \\
=53 \\
\text { control, } n= \\
53\end{array}$ & $\begin{array}{l}\text { ESI, } \\
\text { peritonitis, } \\
\text { technical } \\
\text { failure }\end{array}$ & Funding source was not stated. \\
\hline $\begin{array}{l}\text { Bernadini } \\
\text { et al. [19] }\end{array}$ & $\begin{array}{l}\text { RCT } 53.8 \\
\text { patient- } \\
\text { years for M, } \\
64.3 \\
\text { patient- } \\
\text { years for } \mathrm{G}\end{array}$ & $\begin{array}{l}\text { Countries, } \\
\text { United } \\
\text { States; } \\
\text { setting, } \\
\text { multicenter }\end{array}$ & $\begin{array}{l}\text { Both incident and } \\
\text { prevalent PD } \\
\text { patients enrolled } \\
\text { in a registry at } \\
\text { three centers. }\end{array}$ & $\begin{array}{l}\text { Allergy to mupirocin or } \\
\text { gentamicin, peritonitis or } \\
\text { ESI within a month }\end{array}$ & $\begin{array}{l}\text { Mupirocin, } n \\
=66 ; \\
\text { gentamicin, } \\
n=67\end{array}$ & $\begin{array}{l}\text { ESI, } \\
\text { peritonitis, } \\
\text { technical } \\
\text { failure }\end{array}$ & $\begin{array}{l}\text { This study was supported by the } \\
\text { National Kidney Foundation of } \\
\text { Western Pennsylvania, National } \\
\text { Kidney Foundation of Upstate } \\
\text { New York, and the Paul Teschan } \\
\text { Fund of Dialysis Clinic, Inc. }\end{array}$ \\
\hline $\begin{array}{l}\text { Chu et al. } \\
{[9]}\end{array}$ & $\begin{array}{l}\text { RCT } 44.9 \\
\text { patient- } \\
\text { years for M, } \\
39.6 \\
\text { patient- } \\
\text { years for } \mathrm{G}\end{array}$ & $\begin{array}{l}\text { Countries, } \\
\text { Hong } \\
\text { Kong; } \\
\text { setting, } \\
\text { single } \\
\text { center }\end{array}$ & $\begin{array}{l}\text { Both incident and } \\
\text { prevalent PD } \\
\text { patients }\end{array}$ & $\begin{array}{l}\text { Allergy to mupirocin or } \\
\text { gentamicin, peritonitis or } \\
\text { ESI within } 4 \text { weeks, active } \\
\text { infection }\end{array}$ & $\begin{array}{l}\text { Mupirocin } n \\
=38 \\
\text { gentamicin, } \\
n=43 ; \\
\text { dropout, } n= \\
14\end{array}$ & $\begin{array}{l}\text { ESI, } \\
\text { peritonitis, } \\
\text { technical } \\
\text { failure }\end{array}$ & Funding source was not stated. \\
\hline $\begin{array}{l}\text { Mortazavi } \\
\text { et al. [17] }\end{array}$ & $\begin{array}{l}\text { RCT } 29.8 \\
\text { patient- } \\
\text { years for M, } \\
29.4 \\
\text { patient- } \\
\text { years for G }\end{array}$ & $\begin{array}{l}\text { Countries, } \\
\text { Iran; } \\
\text { setting, } \\
\text { single } \\
\text { center }\end{array}$ & & $\begin{array}{l}\text { Use of antibiotics within a } \\
\text { month, allergy to } \\
\text { mupirocin or gentamicin }\end{array}$ & $\begin{array}{l}\text { Mupirocin, } n \\
=61 ; \\
\text { gentamicin, } \\
n=60 ; \\
\text { dropout, } n= \\
10\end{array}$ & $\begin{array}{l}\text { Peritonitis, } \\
\text { technical } \\
\text { failure }\end{array}$ & Funding source was not stated. \\
\hline
\end{tabular}

$R C T$ randomized controlled trial, $P D$ peritoneal dialysis, ESI exit site infection, $C$ control, $M$ application of mupirocin ointment to exit site, $G$ application of gentamicin ointment on the exit site

prevents ESI, peritonitis, or technical failure because the certainty of this evidence is very low, although we examined the effects of such topical application by focusing only on randomized studies. Thus, there is insufficient evidence with respect to the recommendation of the topical application of antibiotics on the exit site to prevent PD-related infections or technical failure.

Our findings were contrary to the previous review of 14 RCTs, historical cohorts, or meta-analysis regarding the prevention of ESI and peritonitis through the application of mupirocin ointment [13]. They reported that the application of mupirocin ointment decreased the risk of ESI by $57 \%$ and the risk of peritonitis by $41 \%$ compared with the control group. In response to these findings, the 2017 ISPD guidelines reported that the application of antibiotic ointment on the exit site was effective in preventing PD-related infections; hence, the practice was recommended [7]. However, the problem with the report by $\mathrm{Xu}$ et al. is that it included studies on not only the application of mupirocin ointment on the exit site but also the nasal application of mupirocin ointment, and these studies were targeted towards patients who harbored $S$. aureus in their nasal cavities [13]. Our meta-analysis included only randomized studies that used only adult cases as subjects, and we used 6 RCTs after excluding the application of antibiotic ointment to the nasal cavity. Three studies compared the mupirocin ointment group and the control group [16, 18, 34], and only 3 studies compared the mupirocin and gentamicin ointment groups $[9,17,19]$. Among the RCTs we used, only 1 overlapped with the report by $\mathrm{Xu}$ et al. [13]. This 
Table 2 Risk of bias

\begin{tabular}{|c|c|c|c|c|c|c|c|c|}
\hline \multirow{3}{*}{ Studies } & \multicolumn{8}{|c|}{ Risk of bias } \\
\hline & \multirow{2}{*}{$\begin{array}{l}\text { Random } \\
\text { sequence } \\
\text { generation }\end{array}$} & \multirow{2}{*}{$\begin{array}{l}\text { Allocation } \\
\text { concealment }\end{array}$} & \multicolumn{2}{|c|}{ Blinding } & \multirow{2}{*}{$\begin{array}{c}\text { Incomplete } \\
\text { outcome } \\
\text { data }\end{array}$} & \multirow{2}{*}{$\begin{array}{l}\text { Selective } \\
\text { outcome } \\
\text { reporting }\end{array}$} & \multirow{2}{*}{$\begin{array}{c}\text { Other } \\
\text { sources of } \\
\text { bias }\end{array}$} & \multirow{2}{*}{$\begin{array}{c}\text { Risk of } \\
\text { bias within } \\
\text { a study }\end{array}$} \\
\hline & & & $\begin{array}{l}\text { Participants } \\
\text { and personnel }\end{array}$ & $\begin{array}{l}\text { Outcome } \\
\text { assessors }\end{array}$ & & & & \\
\hline Wong 2003 & (?) & (?) & 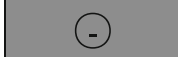 & $\oplus$ & & ? & & ?? \\
\hline Olga 2016 & ? & ? & $\odot$ & $\oplus$ & ? & ? & & ? \\
\hline Findlay 2013 & ? & (?) & $\odot$ & $\oplus$ & $\oplus$ & (?) & & ? \\
\hline Bernardini 2005 & (†) & $\oplus$ & (†) & $\oplus$ & $\oplus$ & ? & † & (†) \\
\hline Chu 2008 & 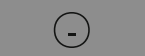 & ? & (?) & $\oplus$ & G & (?) & & ? \\
\hline Mortazavi 2011 & ? & ? & $\oplus$ & $\oplus$ & $\odot$ & $\oplus$ & & ? \\
\hline
\end{tabular}

$\bigodot$ (gray) high risk of bias, $\odot$ (light gray) low risk of bias, ?? (white) unknown risk of bias

might be explained by their limited electronic database search to English articles until 2009. We searched all articles regardless of languages until 2017 and provided more comprehensive findings. Among 3 RCTs we selected, there was a significant heterogeneity. Findlay et al. [18] showed the significant effectiveness of mupirocin on ESI. In contrast, the studies by Olga et al. [16] and Wong et al. [34] exhibited no significance in preventing ESI. In the study by Findlay et al. [18], the prevalence of diabetes was significantly lower in mupirocin group despite random allocation, which might have biased towards less ESI in mupirocin group. However, the prevalence of diabetes was also significantly lower in mupirocin group in the study by Olga et al. [16]. Different exit site care were used in control groups in each study; polyhexamethylene biguanide application in the study by Findlay et al. [18], chlorhexidine application in the study by Olga et al. [16], and chlorhexidine and povidone iodine application in the study by Wong et al. [34], and that might be one of the reasons for the heterogeneity.

We also showed that there was no significant difference in incidence rate of ESIs and peritonitis between mupirocin and gentamicin ointments. This is consistent with a previous meta-analysis [24]. However, their study included retrospective observational studies, which are at risk of indication bias, and studies comparing the incidence rate of ESI or peritonitis before and after changing exit site care with mupirocin to gentamicin ointment. Thus, our results limited to RCTs were more reliable.

There are several strengths of this study. Firstly, our review is the latest comprehensive evidence of the application of topical antibiotics on the exit site in PD patients. We followed rigorous methodology to perform SR and meta-analysis. Our findings provided insights into the previous recommendations of the application of topical antibiotics in all PD patients. Thus, our findings may aid in changing this practice in other countries where antibiotics are routinely applied on the exit site. For example, 56\% of the PD patients applied mupirocin in Australia/New Zealand [36]. Furthermore, we found that no study has evaluated the long-term side effects of antibiotic use. Only a few studies reported the side effects of antibiotic use, especially its effects on the skin [16, 18]. This is a matter of concern since the possibility of increasing the growth of mupirocin- and gentamicin-resistant bacteria emerges because of long-term preventive administration of this antibiotic. Previous observational studies reported that mupirocin-resistant $S$. aureus was detected in approximately $3 \%$ of patients after long-term 
A. Exit site infection

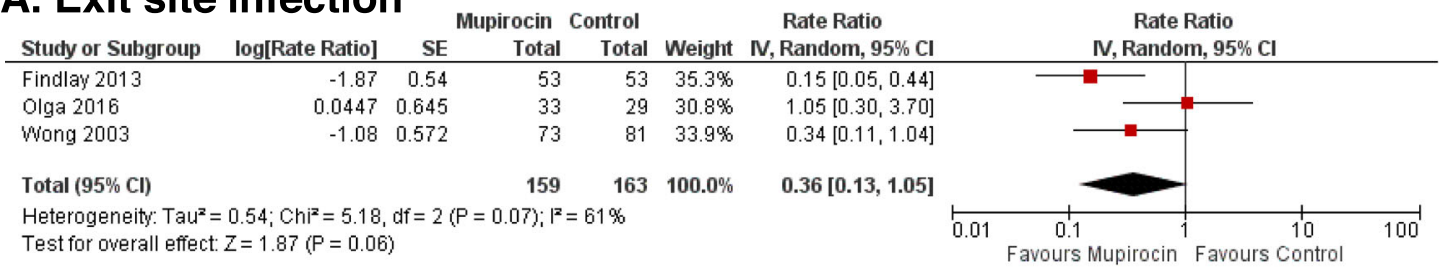

\section{B. Peritonitis}

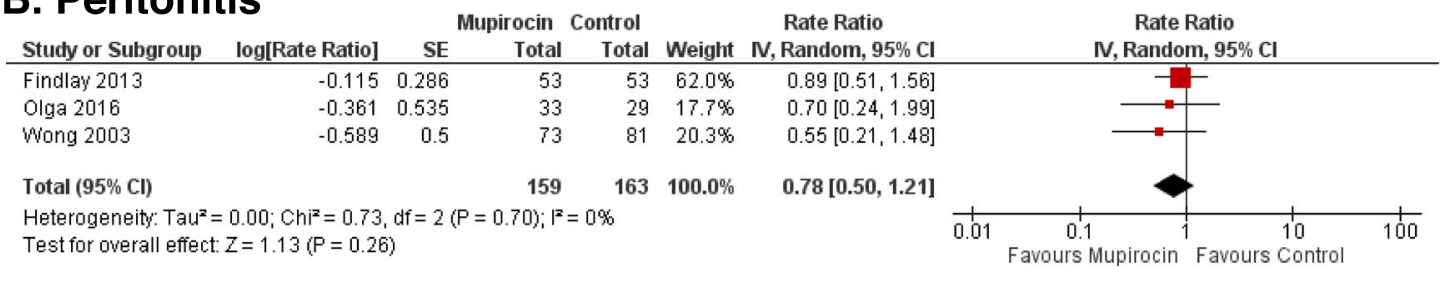

\section{Technical Failure}

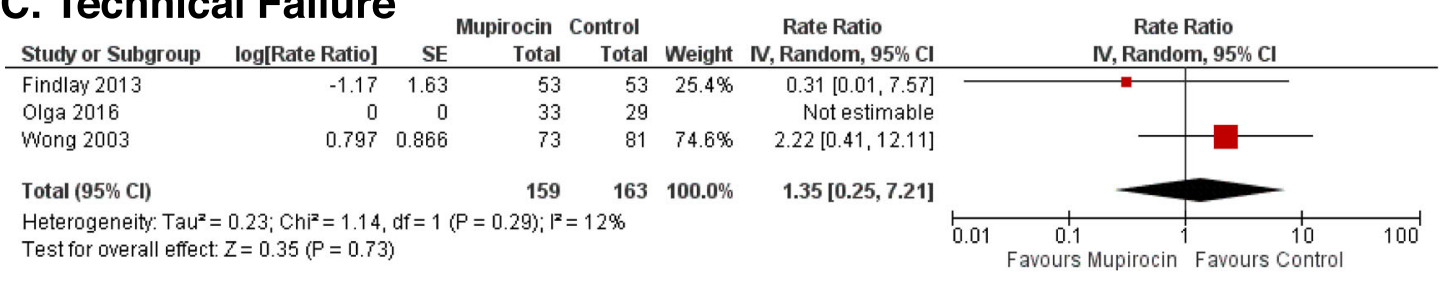

\section{Exit site infection}

Mupirocin vs Gentamicin

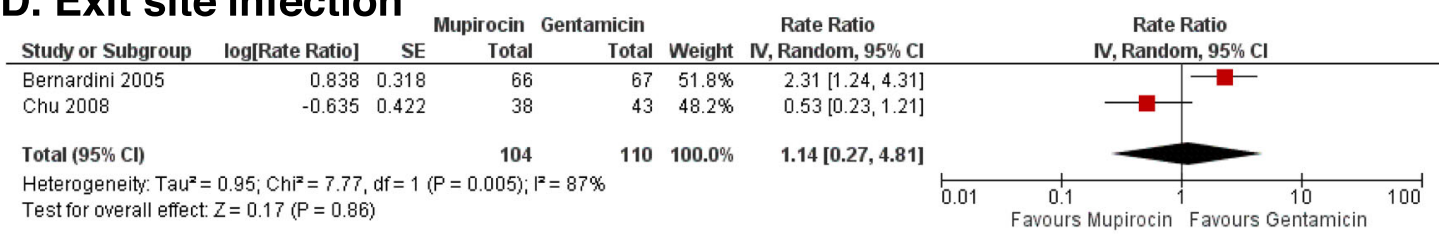

\section{E. Peritonitis}

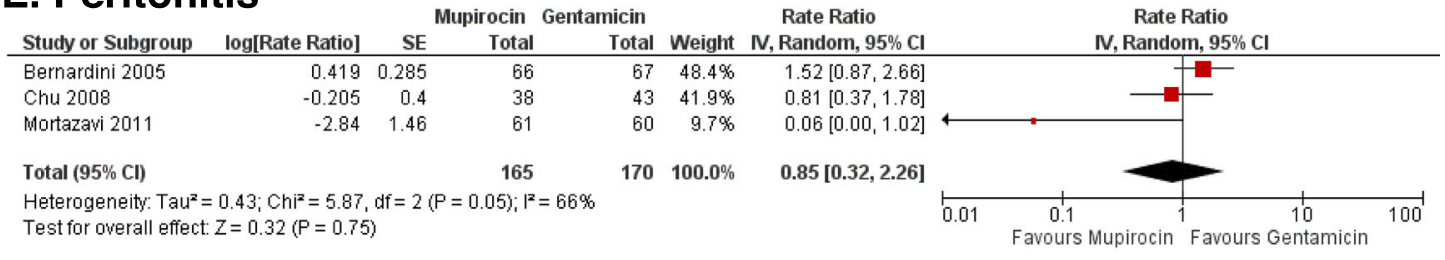

\section{F. Technical Failure}

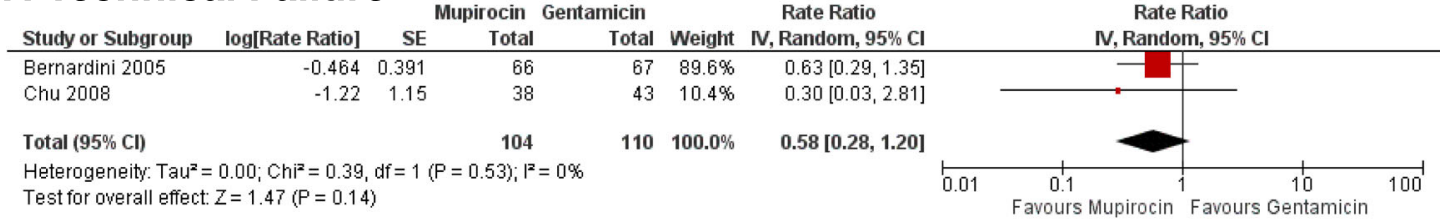

Fig. 2 Comparison between the mupirocin ointment group and control group (a-c) or comparison between the mupirocin ointment group and gentamicin ointment group (d-f). Outcomes were ESI (a, d), peritonitis $(\mathbf{b}, \mathbf{e})$, and technical failure $(\mathbf{c}, \mathbf{f})$ 
Table 3 Summary of findings

\begin{tabular}{|c|c|c|c|c|c|}
\hline \multirow[t]{2}{*}{ Outcomes } & \multicolumn{2}{|c|}{ Illustrative comparative risk (event/100 patient-years) $(95 \%$ Cl) } & \multirow{2}{*}{$\begin{array}{l}\text { Rate ratio (95\% } \\
\text { Cl) }\end{array}$} & \multirow{2}{*}{$\begin{array}{l}\text { No. of } \\
\text { participants } \\
\text { (studies) }\end{array}$} & \multirow{2}{*}{$\begin{array}{l}\text { Quality of } \\
\text { the } \\
\text { evidence } \\
\text { (GRADE) }\end{array}$} \\
\hline & Control or gentamicin & Mupirocin & & & \\
\hline \multicolumn{6}{|c|}{ Comparison between the mupirocin ointment group and control group } \\
\hline Exit-site infection & 27.7 & $10.0(3.6-29.1)$ & $0.36(0.13-1.05)$ & 322 (3 studies) & $\begin{array}{l}\oplus \circ 0 \bigcirc \\
\text { Very low }\end{array}$ \\
\hline Peritonitis & 29.7 & $23.2(14.9-35.9)$ & $0.78(0.50-1.21)$ & 322 (3 studies) & $\begin{array}{l}\oplus \oplus \mathrm{OO}^{* 2} \\
\text { LoW }\end{array}$ \\
\hline Technical failure & 2.0 & $2.7(0.5-14.4)$ & $1.35(0.25-7.21)$ & 322 (3 studies) & $\begin{array}{l}\oplus \oplus \circ 0^{* 3} \\
\text { LoW }\end{array}$ \\
\hline \multicolumn{6}{|c|}{ Comparison between the mupirocin ointment group and the gentamicin ointment group } \\
\hline Exit-site infection & 28.9 & $32.9(7.8-138.8)$ & $1.14(0.27-4.81)$ & 214 (2 studies) & $\begin{array}{l}\oplus 000^{* 4} \\
\text { Very low }\end{array}$ \\
\hline Peritonitis & 32.3 & $27.4(10.3-72.9)$ & $0.85(0.32-2.26)$ & 335 (3 studies) & $\begin{array}{l}\oplus \oplus \circ 0^{* 5} \\
\text { LoW }\end{array}$ \\
\hline Technical failure & 16.5 & 9.6 (4.6-19.8) & $0.58(0.28-1.20)$ & 214 (3 studies) & $\begin{array}{l}\oplus \oplus \circ{ }^{* 6} \\
\text { Low }\end{array}$ \\
\hline
\end{tabular}

${ }^{* 1}$ Serious unexplained heterogeneity, based on studies with high risk of bias

${ }^{*}$ Based on studies with high risk of bias

${ }^{*}$ Increased risk of bias related to incomplete outcome data and selective reporting, based on studies with high risk of bias

${ }^{*}$ Increased risk of bias related to incomplete outcome data and selective reporting, based on studies with high risk of bias, serious unexplained heterogeneity

${ }^{*}$ Increased risk of bias related to incomplete outcome data and selective reporting, based on studies with high risk of bias, serious unexplained heterogeneity

${ }^{*}$ Increased risk of bias related to incomplete outcome data and selective reporting, based on studies with high risk of bias

application of mupirocin ointment on the exit site [37, 38]. A report described cases treated with the application of mupirocin ointment on the exit site for the prevention of PD-related infection and stated that mupirocin-resistant bacteria accounted for $16.7 \%$ of ESIs due to gram-positive bacteria [39]. Another report indicated that the application of gentamicin ointment reduced the susceptibility to Enterobacteriaceae and Pseudomonas [40] and caused many cases of ESI or peritonitis due to nontuberculous mycobacteria [41]. However, much remains unclear about the frequency of the appearance of drugresistant bacteria and the phenomenon of microbial substitution due to the application of antibiotic ointment over a long period. Thus, these matters should be considered in the future studies.

Meanwhile, there are several limitations in our study. First, the number of studies that met the entry criteria was small, resulting in the imprecisions of treatment effect estimates in this SR. Also, we could hardly determine publication bias with only two or three studies included. Second, the follow-up period for this study was limited in 1 to 3 months, which may have been too short to observe the difference in technical survival because of the small number of events. Thus, we might find no significant difference in technical survival between the mupirocin and antibiotic ointment groups and between the mupirocin and gentamicin ointment groups, although technical survival is an important outcome affecting the prognosis of patients. We hope that long-term prospective study will clarify the effect on technical survival. Third, six articles included in the present study were from different countries and may have included subjects with different backgrounds in the population assessed for the exit site care. Since the regional variation is reported in the treatment and prevention of PD-related infections [36], these factors may have affected the results. To solve this problem, global large-scale study targeted to PD patients in various countries should be considered.

\section{Conclusions}

There was insufficient evidence to recommend the routine application of topical antibiotics on the exit site for the prevention of PD-related infections. Additionally, no study has evaluated the long-term side effects of antibiotic application on the exit site. In the light of these results, a large-scale randomized and prospective trial should be conducted to prove the efficacy of the application of antibiotic ointment on the exit site for the prevention of PD-related infection and to assess the side effects of the longterm application of antibiotics.

\section{Appendix}

Electronic databases (Medline and Cochrane Central Register of Controlled Trials) were searched using the 
following terms: "peritoneal dialysis," "mupirocin," "gentamicin," and "anti-bacterial agents." To identify the preexisting CPGs and SRs, the references cited in these guidelines and SRs were evaluated. To identify more recent articles missed by the initial search, an electronic database search was performed in MEDLINE (from April 2016, up to when the most recent systematic review was evaluated, to April 2017) using the following terms: "peritoneal dialysis," "mupirocin," "gentamicin," "anti-bacterial agents," and "randomized controlled trial."

\section{Abbreviations \\ CENTRAL: Cochrane Central Register of Controlled Trials; Cl: Confidence interval; CPG: Clinical practice guideline; ESI: Exit-site infection; ISPD: International Society for Peritoneal Dialysis; MRSA: Methicillin-resistant Staphylococcus aureus; PD: Peritoneal dialysis; PRISMA: Preferred Reporting Items for Systematic Reviews and Meta-analyses; RCT: Randomized controlled trial; RR: Rate ratio; SR: Systematic review}

\section{Acknowledgements}

We appreciate all the members of Working Group on Revision of Peritoneal Dialysis Guidelines, Japanese Society for Dialysis Therapy for the support and advice and also the staffs of Japanese Society for Dialysis Therapy for the support.

\section{Authors' contributions}

Contributions of authors are as follows: conception and design of the study, YO, MT, NT, SY, YOT, YaT, and HT; analysis and interpretation of data, YO, MT, $N T$, SY, YoT, YaT, and HT; drafting the article or revising it, YO, MT, NT, SY, YoT, YaT, and $\mathrm{HT}$; and providing intellectual content of critical importance to the work described, $\mathrm{HY}, \mathrm{MR}, \mathrm{YI}, \mathrm{TT}$, and HN. All authors read and approved the final manuscript.

\section{Funding}

The study was supported by Japanese Society for Dialysis Therapy.

\section{Availability of data and materials}

Data sharing is not applicable to this article as this is a systematic review of published studies.

\section{Ethics approval and consent to participate}

No ethical approval was required because this study is a systematic review of published studies, did not include confidential personal data, and did not involve patient intervention.

\section{Consent for publication}

Not applicable

\section{Competing interests}

The authors declare that they have no competing interests.

\section{Author details}

'Working Group on Revision of Peritoneal Dialysis Guidelines, Japanese Society for Dialysis Therapy, 2-38-21, Hongo, Bunkyo-ku, Tokyo 1130033, Japan. ${ }^{2}$ Department of Nephrology, Nagasaki University Hospital, 1-7-1 Sakamoto, Nagasaki 8528501, Japan. ${ }^{3}$ Department of Nephrology, Nagoya City University Graduate School of Medical Sciences, 1-Kawasumi, Mizuho-cho, Mizuho-ku, Nagoya 467-8601, Japan. ${ }^{4}$ Department of Nephrology, Kansai Electric Power Hospital, 2-1-7, Fukushima, Fukushima-ku, Osaka 553-0003, Japan. ${ }^{5}$ Department of Nephrology, Wakayama Medical University, 811-1, Kimii-dera, Wakayama-shi, Wakayama 6418509, Japan. ${ }^{6}$ Department of Internal Medicine, Inoue Hospital, 16-17, Enoki-cho, Suita-shi, Osaka 564-0053, Japan. ${ }^{7}$ Department of Nephrology and Dialysis, Kyoritsu Hospital, 16-5 Chuo-cho, Kawanishi, Hyogo 666-0016, Japan. ${ }^{8}$ Hospital Care Research Unit, Hyogo Prefectural Amagasaki General Medical Center, Higashi-Naniwa-Cho 2-17-77, Amagasaki, Hyogo 660-8550, Japan. ${ }^{9}$ Department of Oral and Maxillofacial Surgery, National Hospital
Organization Toyohashi Medical Center, 50, Imure-chou Aza Hamamichi-Ue, Toyohashi-shi, Aichi 440-8510, Japan. ${ }^{10}$ Division of Nephrology, Department of Internal Medicine, Tokyo Saiseikai Central Hospital, 1-4-17 Mita, Minato-ku, Tokyo 108-0073, Japan. ${ }^{11}$ Department of Nephrology and Rheumatology, Aichi Medical University, 1-1 Yazakokarimata, Nagakute, Aichi 480-1195, Japan. ${ }^{12}$ Clinical Engineering Research Center, Oita University Faculty of Medicine, 1-1 Idaigaoka, Hasama-cho, Yufu, Oita 879-5593, Japan.

${ }^{13}$ Department of General Internal Medicine, Saitama Medical University, 38 Moro-hongo, Moroyama-machi, Iruma-gun, Saitama 350-0495, Japan.

Received: 15 January 2020 Accepted: 18 February 2020

Published online: 04 March 2020

\section{References}

1. Masakane I, Taniguchi M, Nakai S, Tsuchida K, Goto S, Wada A, et al. Annual dialysis data report 2015, JSDT Renal Data Registry. Ren Replace Ther. 2018; 4:19.

2. Masakane I, Taniguchi M, Nakai S, Tsuchida K, Wada A, Ogata S, et al. Annual dialysis data report 2016, JSDT Renal Data Registry. Ren Replace Ther. 2018; 4:45.

3. Cho Y, Johnson DW. Peritoneal dialysis-related peritonitis: towards improving evidence, practices, and outcomes. Am J Kidney Dis. 2014;64: 278-89.

4. Lafrance JP, Rahme E, Iqbal S, Elftouh N, Vallée M, Laurin LP, et al. Association of dialysis modality with risk for infection-related hospitalization: a propensity score-matched cohort analysis. Clin J Am Soc Nephrol. 2012;7: 1598-605.

5. Nakayama M, Miyazaki M, Honda K, Kasai K, Tomo T, Nakamoto H, et al. Encapsulating peritoneal sclerosis in the era of a multi-disciplinary approach based on biocompatible solutions: the NEXT-PD study. Perit Dial Int. 2014; 34:766-74.

6. Johnson DW, Dent H, Hawley CM, McDonald SP, Rosman JB, Brown FG, et al. Associations of dialysis modality and infectious mortality in incident dialysis patients in Australia and New Zealand. Am J Kidney Dis. 2009;53 290-7.

7. Szeto CC, Li PK, Johnson DW, Bernardini J, Dong J, Figueiredo AE, et al. ISPD catheter-related infection recommendations: 2017 update. Perit Dial Int. 2017;37:141-54

8. Bernardini J, Piraino B, Holley J, Johnston JR, Lutes R. A randomized trial of Staphylococcus aureus prophylaxis in peritoneal dialysis patients: mupirocin calcium ointment $2 \%$ applied to the exit site versus cyclic oral rifampin. Am J Kidney Dis. 1996;27:695-700.

9. Chu KH, Choy WY, Cheung CC, Fung KS, Tang HL, Lee W, et al. A prospective study of the efficacy of local application of gentamicin versus mupirocin in the prevention of peritoneal dialysis catheter-related infections. Perit Dial Int. 2008:28:505-8.

10. Mahajan S, Tiwari SC, Kalra V, Bhowmik DM, Agarwal SK, Dash SC, et al. Effect of local mupirocin application on exit-site infection and peritonitis in an Indian peritoneal dialysis population. Perit Dial Int. 2005;25:473-7.

11. Strippoli GF, Tong A, Johnson D, Schena FP, Craig JC. Antimicrobial agents for preventing peritonitis in peritoneal dialysis patients. Cochrane Database Syst Rev. 2004;4:CD004679.

12. Strippoli GF, Tong A, Johnson D, Schena FP, Craig JC. Catheter-related interventions to prevent peritonitis in peritoneal dialysis: a systematic review of randomized, controlled trials. J Am Soc Nephrol. 2004;15:2735-46.

13. $\mathrm{Xu} G, T u \mathrm{~W}, \mathrm{Xu}$ C. Mupirocin for preventing exit-site infection and peritonitis in patients undergoing peritoneal dialysis. Nephrol Dial Transplant. 2010;25: $587-92$.

14. Piraino B, Bernardini J, Florio T, Fried L. Staphylococcus aureus prophylaxis and trends in gram-negative infections in peritoneal dialysis patients. Perit Dial Int. 2003:23:456-9.

15. Higgins J.P.T, Green S (editors). Cochrane Handbook for Systematic Reviews of Interventions Version 5.1.0 [updated March 2011]. The Cochrane Collaboration. 2011. Available from www.handbook.cochrane.org.

16. Olga B, Fotis Z, Margarita I, Sofia X, Konstantinos S. Chlorhexidine for routine PD catheter exit-site care. Int Urol Nephrol. 2016:48:1543-6.

17. Mortazavi M, Halabian M, Seirafian S, Emami A, Farajzadegan Z, Moinzadeh $F$, et al. The effect of topical gentamicin and mupirocin on peritonitis and exit site infection in peritoneal dialysis. J Isfahan Med Sch. 2011;28:69-76.

18. Findlay A, Serrano C, Punzalan S, Fan SL. Increased peritoneal dialysis exit site infections using topical antiseptic polyhexamethylene biguanide 
compared to mupirocin: results of a safety interim analysis of an open-label prospective randomized study. Antimicrob Agents Chemother. 2013;57: 2026-8.

19. Bernardini J, Bender F, Florio T, Sloand J, Palmmontalbano L, Fried L, et al. Randomized, double-blind trial of antibiotic exit site cream for prevention of exit site infection in peritoneal dialysis patients. J Am Soc Nephrol. 2005; 16:539-45.

20. Moher D, Liberati A, Tetzlaff J, Altman DG, Group P. Preferred reporting items for systematic reviews and meta-analyses: the PRISMA statement. BMJ. 2009:339:b2535.

21. Higgins JP, Altman DG, Gøtzsche PC, Jüni P, Moher D, Oxman AD, et al. The Cochrane Collaboration's tool for assessing risk of bias in randomised trials. BMJ. 2011;343:d5928.

22. Guyatt GH, Oxman AD, Vist GE, Kunz R, Falck-Ytter Y, Alonso-Coello P, et al. GRADE: an emerging consensus on rating quality of evidence and strength of recommendations. BMJ. 2008;336:924-6.

23. Higgins JP, Thompson SG, Deeks JJ, Altman DG. Measuring inconsistency in meta-analyses. BMJ. 2003;327:557-60.

24. Tsai CC, Yang PS, Liu CL, Wu CJ, Hsu YC, Cheng SP. Comparison of topical mupirocin and gentamicin in the prevention of peritoneal dialysis-related infections: a systematic review and meta-analysis. Am J Surg. 2018;215:179-85.

25. Campbell D, Mudge DW, Craig JC, Johnson DW, Tong A, Strippoli GF. Antimicrobial agents for preventing peritonitis in peritoneal dialysis patients. Cochrane Database Syst Rev. 2017:4:CD004679.

26. Grothe C, Taminato M, Belasco A, Sesso R, Barbosa D. Prophylactic treatment of chronic renal disease in patients undergoing peritoneal dialysis and colonized by staphylococcus aureus: a systematic review and metaanalysis. BMC Nephrol. 2016;17:115.

27. Kopriva-Altfahrt G, Moser E, Prokschi A, Kraus B, Kovarik J. Prophylaxis and management of catheter-associated infections in peritoneal dialysis patients: recent studies and guidelines. Wien Klin Wochenschr. 2005; 117(Suppl 6):73-82

28. Lockwood C, Hodgkinson B, Page T. Clinical effectiveness of different approaches to peritoneal dialysis catheter exit-site care. JBI Libr Syst Rev. 2003;1:1-52.

29. Tacconelli E, Carmeli Y, Aizer A, Ferreira G, Foreman MG, D'Agata EM. Mupirocin prophylaxis to prevent staphylococcus aureus infection in patients undergoing dialysis: a meta-analysis. Clin Infect Dis. 2003;37: 1629-38.

30. Amici G, Russo R, Feriani M, Corciulo R, D'Amico M, De Vecchi A, et al. Antimicrobial agents for preventing peritonitis in peritoneal dialysis: guideline from the Italian Society of Nephrology. G Ital Nefrol. 2007;37: S125-35.

31. Piraino B, Bailie GR, Bernardini J, Boeschoten E, Gupta A, Holmes C, et al. Peritoneal dialysis-related infections recommendations: 2005 update. Perit Dial Int. 2005;25:107-31.

32. McCormack K, Rabindranath K, Kilonzo M, Vale L, Fraser C, Mclntyre L, et al. Systematic review of the effectiveness of preventing and treating Staphylococcus aureus carriage in reducing peritoneal catheter-related infections. Health Technol Assess. 2007;11 iii-iv, ix-x, 1-66.

33. Santarelli S, Amici G, Bernacconi T, Bonforte G, Ceraudo E, Dell'Aquila R, et al. The peritoneal dialysis catheter. J Nephrol. 2013;21:4-75.

34. Wong SS, Chu KH, Cheuk A, Tsang WK, Fung SK, Chan HW, et al. Prophylaxis against gram-positive organisms causing exit-site infection and peritonitis in 1 continuous ambulatory peritoneal dialysis patients by applying mupirocin ointment at the catheter exit site. Perit Dial Int. 2003;2:S153-8.

35. Balafa O, Zarzoulas F, Ikonomou M, Xiromeriti S, Siamopoulos K. Erratum to: chlorhexidine for routine PD catheter exit-site care. Int Urol Nephrol. 2017:49:365.

36. Boudville N, Johnson DW, Zhao J, Bieber BA, Pisoni RL, Piraino B, et al. Regional variation in the treatment and prevention of peritoneal dialysisrelated infections in the peritoneal dialysis outcomes and practice patterns study. Nephrol Dial Transplant. 2018; Epub ahead of print.

37. Lobbedez T, Gardam M, Dedier H, Burdzy D, Chu M, Izatt S, et al. Routine use of mupirocin at the peritoneal catheter exit site and mupirocin resistance: still low after 7 years. Nephrol Dial Transplant. 2004;19:3140-3.

38. Annigeri R, Conly J, Vas S, Dedier H, Prakashan KP, Bargman JM, et al. Emergence of mupirocin-resistant staphylococcus aureus in chronic peritoneal dialysis patients using mupirocin prophylaxis to prevent exit-site infection. Perit Dial Int. 2001;21:554-9.

39. Al-Hwiesh AK, Abdul-Rahman IS, Al-Muhanna FA, Al-Sulaiman MH, AlJondebi MS, Divino-Filho JC. Prevention of peritoneal dialysis catheter infections in Saudi peritoneal dialysis patients: the emergence of high-level mupirocin resistance. Int J Artif Organs. 2013;36:473-83.

40. Pierce DA, Williamson JC, Mauck VS, Russell GB, Palavecino E, Burkart JM. The effect on peritoneal dialysis pathogens of changing topical antibiotic prophylaxis. Perit Dial Int. 2012;32:525-30.

41. Lo MW, Mak SK, Wong YY, Lo KC, Chan SF, Tong GM, et al. Atypical mycobacterial exit-site infection and peritonitis in peritoneal dialysis patients on prophylactic exit-site gentamicin cream. Perit Dial Int. 2013;33: $267-72$.

\section{Publisher's Note}

Springer Nature remains neutral with regard to jurisdictional claims in published maps and institutional affiliations.
Ready to submit your research? Choose BMC and benefit from:

- fast, convenient online submission

- thorough peer review by experienced researchers in your field

- rapid publication on acceptance

- support for research data, including large and complex data types

- gold Open Access which fosters wider collaboration and increased citations

- maximum visibility for your research: over $100 \mathrm{M}$ website views per year

At $\mathrm{BMC}$, research is always in progress.

Learn more biomedcentral.com/submissions 